\title{
The Life Sciences Learning Center: An Evolving Model for a Sustainable STEM Outreach Program
}

\author{
Danielle C. Alcéna-Stiner ${ }^{1,2}$ and Dina G. Markowitz ${ }^{2}$ \\ ${ }^{1}$ School of Nursing, University of Rochester Medical Center, Rochester, New York and ${ }^{2}$ Department of Environmental Medicine, University of Rochester, Rochester, \\ New York \\ Keywords: Curriculum Development, Teacher Professional Development, Secondary Science Education, Science Outreach, Summer Science Program, Informal \\ Science Education, STEM Outreach, Health Literacy \\ Publication Date: August 10, 2020 \\ DOI: https://doi.org/10.15695/jstem/v3i2.08
}

\begin{abstract}
The Life Sciences Learning Center (LSLC) is a hands-on science outreach center located at the University of Rochester's School of Medicine and Dentistry (UR-SMD) in Rochester, NY. The LSLC provides hands-on, case-based learning to boost science literacy and increase enthusiasm toward science learning. The LSLC offers on-site and in-school programs for secondary students (grades 6-12) and has developed a wide variety of online curriculum materials that can be used in science classrooms and informal education settings. The LSLC is a model for sustainability with over 20 years of funding through a combination of sources including numerous grant awards from National Institutes of Health (NIH) and private foundations. The LSLC was awarded its first of five NIH Science Education Partnership Awards (SEPA) in 1998, which would prove to be a key funding source for sustainability. The LSLC has widely disseminated its curriculum materials nationwide through teacher professional development programs and online. An ongoing partnership with Science Take-Out has led to further dissemination of LSLC's curriculum materials and has strengthened LSLC's model for curriculum development and evaluation. The LSLC has evolved over the years to meet the changing needs of teachers and their students and the increased demands for hands-on, inquiry-based learning that focuses on real-life issues in STEM.
\end{abstract}

\section{INTRODUCTION}

The Life Sciences Learning Center (LSLC) is a hands-on science outreach center located at the University of Rochester's School of Medicine and Dentistry (UR-SMD) in Rochester, NY. Dr. Dina Markowitz (LSLC founder/director) was initially hired to lead a variety of pre-college programs that were administered and funded through various UR-SMD departments in 1995. In 1998, Dr. Markowitz became a faculty member in the UR Department of Environmental Medicine's Environmental Health Sciences Center (EHSC), where she served as Director of the EHSC's Community Outreach and Education Programs. In 2001, the LSLC was established within the EHSC to provide hands-on, case-based learning to boost science literacy and increase enthusiasm toward science learning among students, primarily in secondary education (grades 6-12). The LSLC currently offers outreach programs through its UR facility and classroom curriculum materials that can be used in schools and informal education settings.

LSLC's hands-on outreach programs include on-site Field Trips to the center and programs held in schools or at locations throughout the greater Rochester community. The LSLC facility can accommodate up to 30 learners per day in its two fully equipped teaching laboratories. LSLC outreach programs are led by UR faculty, post-doctoral trainees, and graduate students. Undergraduate students also assist in lab preparations for experiential LSLC outreach programs. LSLC Field Trips include use of an array of modern laboratory equipment and supplies such as electrophoresis equipment and micropipettes.

The LSLC utilizes hands-on, laboratory simulations of advanced science technologies and concepts such as enzyme-linked immunosorbent assays (ELISA) and polymerase chain reaction (PCR). These LSLC simulations are used to address time and financial constraints of middle and high school classes, while also providing authentic experimental wet labs for learners. LSLC Field Trip lessons are further modified for mobility outside of the UR as part of the On-the-Road programming, for example substituting a "paper gel" for an electrophoresis set-up. Occasionally, the center also provides On-the Road outreach programming for adult community groups in the Greater Rochester area who are eager to learn about advanced science concepts.

The Life Sciences Learning Center's website (https:// www.urmc.rochester.edu/life-sciences-learning-center.aspx) hosts a wide variety of ready-to-use lessons, available for free downloading. The website enables broad dissemination of LSLC lessons to educators throughout the world. 




Figure 1. Sustainable federal and private foundation grant funding. Timeline depicts key sources of support awarded to the Life Sciences Learning Center (LSLC) and the establishment of Science Take-Out (STO). Acronyms: Howard Hughes Medical Institute (HHMI), National Institutes of Health (NIH), Science Education Partnership Award (SEPA), National Institute of Environmental Health Sciences (NIEHS), Science Education Drug Abuse Partnership Award (SEDAPA), National Institute on Drug Abuse (NIDA).

\section{PROGRAM DESCRIPTION}

Breadth of LSLC Programs. The main mission of the LSLC is to provide pre-college students with hands-on, experiential learning activities across the life sciences. The focus of LSLC programming is to engage students in learning science through hands-on activities which are (usually) different than they experience in their everyday science classrooms. Another mission of the LSLC is to foster partnerships among biological scientists and science teachers in local secondary education. This is accomplished by cultivating collaborations between classroom teachers through LSLC curriculum development, as LSLC curricula is co-written by LSLC staff, UR scientists, and science teachers. LSLC-hosted teacher professional development programs are another means of bringing together teachers and scientists.

The LSLC's programs have evolved from summer science camps (which were the only programs offered in the early years) to a wide array of on-site, in-school, and community-based programs. In addition, the LSLC has hosted numerous local, state, and national teacher professional development programs and has created 47 lesson modules of curriculum materials available online. These LSLC programs grew each year as new funding sources were obtained (Figure 1). Below is a summary of some of the past and present LSLC programs.

From 1996 (prior to the actual LSLC facility) to 2002 the LSLC hosted the UR Summer Science Academy (SSA), a 2-4-week summer program for high school students which was supported by private foundations (Table 1). The SSA provided an assortment of content areas across the life sciences ranging from hands on immunology, microbiology, molecular biology, genetics, and environmental health activities to minds-on seminars that included bioethics, biocomputing and scientific talks. The SSA programs included guided and independent laboratory components in which students conducted and presented their own mini-research projects. Science teachers (2-4 each summer) also participated as SSA instructors and received materials and supplies for their school classrooms.

Additional LSLC outreach programs in the early years included school field trips to the university (using borrowed UR lab rooms and classrooms) and On-the-Road programs held at schools, the Rochester Museum and Science Center and at other community-based locations.

These early LSLC programs established LSLC's focus on case-based, experiential learning which engages students with science topics and issues that are relevant to their lives. LSLC programs involve students taking on the roles of scientific investigators as they come up with solutions to real-life problems. This type of programming encourages teens to further their science education and explore the many possible options of a STEM career. When former Summer Science Academy (SSA) program participants were surveyed for their perceptions and feelings about their SSA experiences, approximately $80 \%$ ( $\mathrm{N}=96$ respondents) felt that their participation in SSA contributed to their desire to pursue a STEM career path (Markowitz, 2004).

As LSLC funding grew from local foundations, LSLC programs also grew. Foundation support for LSLC programs from 1994-1997 added a middle school Science Explorations Camp, middle and high school vacation science programs, a "What's in Our Water"? water quality education 
Table 1. Private Foundation Funded Projects. Table lists the Life Sciences Learning Center (LSLC) projects funded by foundational support.

\begin{tabular}{llll}
\hline Foundation & Project & Start & End \\
\hline Howard Hughes Medical Institute & Precollege Science Programs & 1994 & 1999 \\
Foundation for Microbiology & Precollege Microbiology Outreach Programs & 1995 & 1997 \\
Eastman Kodak Company & What's in Our Water? Program & 1999 & 2000 \\
Fred and Floy Willmott Foundation & What's in Our Water? Program & 2000 & 2000 \\
Rochester Area Community Foundation & What's in Our Water? Program & 2000 \\
Rochester Area Community Foundation & What's in Our Water? Program & 2000 \\
Toyota USA Foundation & LSLC Lab Skills Development Program & 2002 \\
Braitmeyer Foundation & LSLC Lab Skills Development Program & 2003 \\
Howard Hughes Medical Institute & LSLC Lab Skills Development Program & 2004 \\
Arthur Vining Davis Foundations & Cancer biology - high school curriculum materials & 2003 & 2004 \\
Rochester Area Colleges Center for Excellence in Math and & Mastering Molecular Biology through Manipulative Models & 2010 & 2011 \\
Science & (teacher PD* program) & 2007 \\
Time Warner Cable & Science Buddies - after school science clubs & 2008 \\
\hline
\end{tabular}

*PD: Professional Development

program for students and teachers, and Saturday Morning Science, a monthly series of mini-lectures followed by lab tours and hands-on activities (Table 1).

The LSLC was awarded its first of five NIH Science Education Partnership Awards (SEPA) in 1998, which would prove to be a key funding source for sustainability (Table 2). With the second SEPA grant in 2002, the LSLC became fully established and had its own facility within the University of Rochester's School of Medicine and Dentistry (UR-SMD), resulting in an expansion in LSLC outreach programs (Table 2). Expansions included a larger selection of on-site Field Trips for middle school and high school classes, and on-site after school programs. A partnership was developed with the
Rochester City School District (RCSD), creating the LSLC Lab Skills Development program (2002-2007) which provided remedial support to RCSD high school biology classes (Table 1, Table 3). Using funding from Time Warner Cable, LSLC staff, along with teams of UR graduate and undergraduate students, led Science Buddies after school science clubs at over one dozen local elementary schools from 20102013 (Table 1).

To meet the increasing demands for hands-on STEM programming, the LSLC staff grew to include lab assistants, curriculum writers, additional teaching staff, and graduate student teaching interns. To-date, the LSLC has trained over 30 teaching interns since 2006. LSLC teaching interns

Table 2. National Institutes of Health (NIH) Funded Projects. Table lists the Life Sciences Learning Center (LSLC) projects funded by governmental grant support.

\begin{tabular}{|c|c|c|c|}
\hline NIH Institute and Center & Project & Start & End \\
\hline National Center for Research Resources ${ }^{\mathrm{a}}$ & Science Partnerships for Hands-On Learning - Phase I & 1998 & 2001 \\
\hline $\begin{array}{l}\text { National Institute of Environmental Health } \\
\text { Sciences }\end{array}$ & Problem-Based Learning for Environmental Health & 2000 & 2007 \\
\hline $\begin{array}{l}\text { National Institute of Environmental Health } \\
\text { Sciences }\end{array}$ & CORE: Community Outreach and Education Program & 2000 & 2003 \\
\hline National Center for Research Resources ${ }^{\mathrm{a}}$ & Science Partnerships for Hands-On Learning - Phase II & 2001 & 2004 \\
\hline National Human Genome Research Institute & Problem-Based Learning Unit for Teaching ELSI/Genetics & 2003 & 2006 \\
\hline National Center for Research Resources ${ }^{\mathrm{a}}$ & $\begin{array}{l}\text { Life Sciences Learning Center: Strengthening Connections Between Scientists } \\
\text { and Classroom Learning - Phase I and II }\end{array}$ & 2006 & 2011 \\
\hline National Institute on Drug Abuse ${ }^{b}$ & Problem-Based Learning for Drug Abuse and Addiction Education & 2009 & 2012 \\
\hline NIH Blue Print for Neuroscience ${ }^{c}$ & Neuroscience Activities for Hands-On Learning & 2011 & 2017 \\
\hline $\begin{array}{l}\text { National Institute of General Medical Sciences } \\
\text { and Office of the Director, National Institutes } \\
\text { of Health }^{\mathrm{a}}\end{array}$ & Medicines and Me: Understanding and Using Medicines Safely & 2014 & 2019 \\
\hline National Institute of General Medical Sciences ${ }^{\mathrm{a}}$ & One Health Education: Connecting Humans, Animals & 2019 & 2024 \\
\hline
\end{tabular}






Figure 2. Life Sciences Learning Center Lesson Development Process. Iterative multiple step process for teacher input throughout LSLC curriculum development.

have continued in STEM as mentors, outreach coordinators, formal educators, and more. The LSLC has also supported 1-year sabbaticals for local high school biology teachers to lead LSLC Field Trips and to assist with lesson development.

Partnerships that the LSLC developed early on with the UR Warner School of Education, local public schools, and the New York State Biology Mentor Network were essential in developing curriculum materials that remain in demand by teachers world-wide (Table 3 ). These collaborations helped the LSLC advance and evolve in providing a wide variety of hands-on, experiential learning activities across the life sciences that boost science literacy and laboratory skills (Markowitz, 2004).

LSLC's curriculum writers are master biology teachers who create lessons and hands-on activities that align with New York state and national science education standards, using grade appropriate, structured and exploratory methods that enhance student learning. Indeed, qualitative and quantitative evaluations indicate that LSLC's programs have a positive impact on STEM learning (Luehmann, 2009; Markowitz, 2004). Classroom teachers throughout the United States (US) also participate in LSLC curriculum development and evaluation. Teacher involvement is integrated throughout the lesson development process, including providing input on lesson topics, participation in focus groups, and field-testing the lessons in diverse classroom settings (Figure 2). Teacher-led workshops using LSLC classroom lessons also provide an opportunity for professional development among science teachers throughout the US (Figure 3).

LSLC Participants. The LSLC provided hands-on outreach to over 1,000 participants (mostly grade 6-12 students) during its first year, resulting in Field Trip programs for nearly 80 learners per month (Table 4; Figure 4). During the next 18 years the number of LSLC outreach program participants grew to over 20,000 learners (Table 4). The schools participating in LSLC outreach programs span diverse populations of students from a variety of geographic settings in the greater Rochester, NY area (Table 5). While most LSLC programs have served public schools $(\mathrm{N}=122)$, LSLC programs have also reached private schools $(\mathrm{N}=23)$ and charter schools $(\mathrm{N}=10)$. Middle schools $(\mathrm{N}=30)$ and high schools $(\mathrm{N}=90)$ represented the majority of the grades participating in LSLC outreach programs (Table 5). By 2019, over 21,600 students and 636 teachers had participated in the LSLC outreach programs (Table 4).

LSLC Field Trip Activities. The LSLC is located within an authentic research environment, on a research floor of the UR Medical Center, surrounded by working labs. Walking through the halls from the school bus drop-off site to the LSLC, students catch glimpses of "real science" happening all around them. Upon entering the LSLC teaching laboratories, students are given an official LSLC lab coat which they wear for the duration of their field trip (Figure 6). This

Table 3. Life Sciences Learning Center Partnerships 2002-2008. Table lists sources of key partnerships as well as the projects carried out through collaborations, during the early years of the LSLC.

\begin{tabular}{|c|c|c|}
\hline Partner & Project & Years \\
\hline University of Rochester - Warner School of Education & LSLC Laboratory Skills Development Program & $2002-2007$ \\
\hline University of Rochester - Warner School of Education & $\begin{array}{l}\text { Problem-Based Learning for Environmental Health - Environmental Health } \\
\text { project }\end{array}$ & 2000-2008 \\
\hline Rochester City School District & LSLC Laboratory Skills Development Program & $2002-2007$ \\
\hline NY State Biology Mentor Network & $\begin{array}{l}\text { Problem-Based Learning Unit for Teaching ELSI/Genetics - Family Secrets } \\
\text { project }\end{array}$ & \\
\hline NY State Biology Mentor Network & $\begin{array}{l}\text { Problem-Based Learning for Environmental Health - Environmental Health } \\
\text { project }\end{array}$ & $2005-2008$ \\
\hline NY State Biology Mentor Network & Cancer biology curriculum project & $2007-2008$ \\
\hline
\end{tabular}



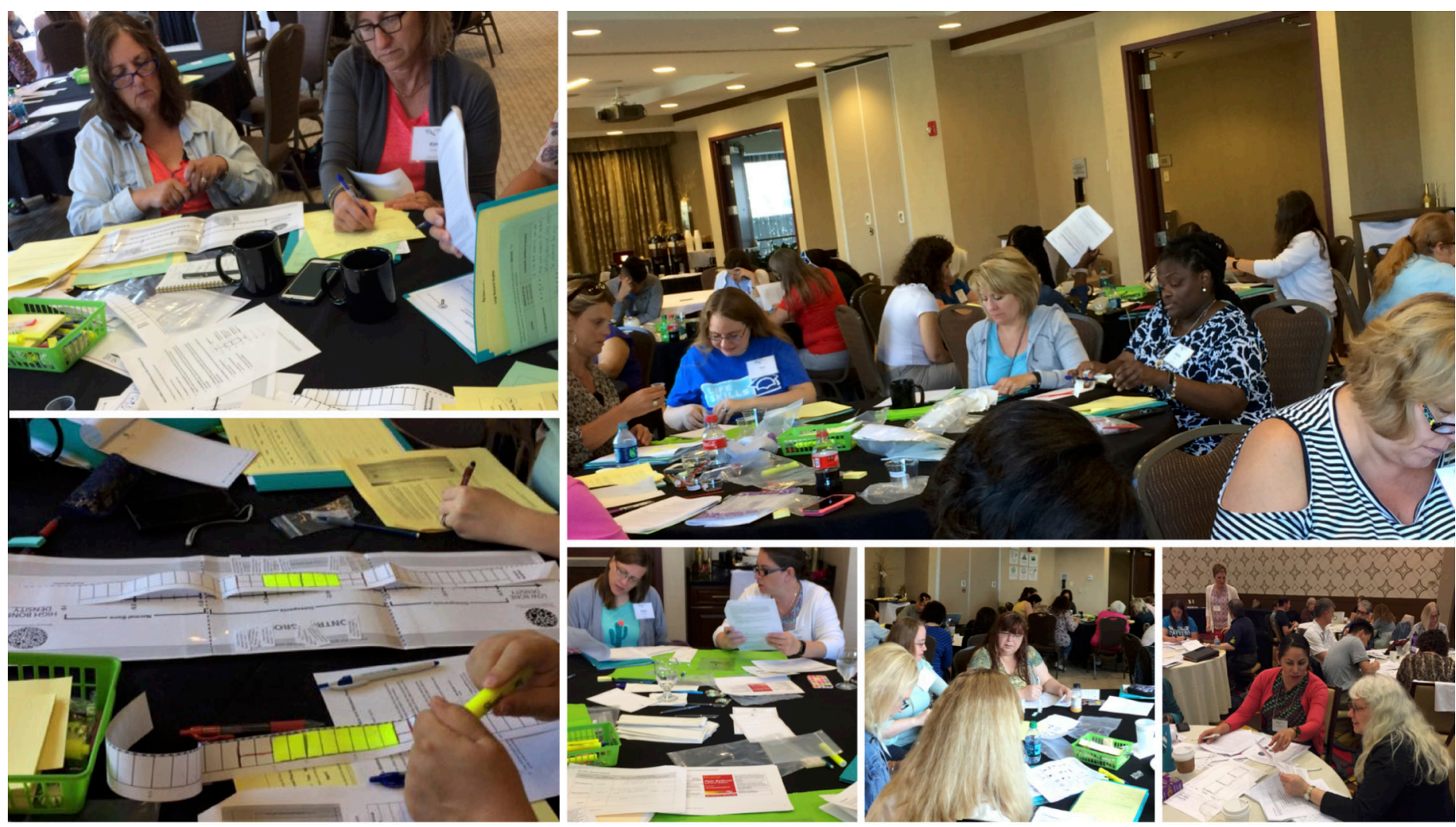

Figure 3. Life Sciences Learning Center Teacher Professional Development. Images depict teachers from around the country gathered for LSLC professional development using hands-on science activities for use in their classroom settings.

first transition into their experiential lab experience is met with excitement as the students begin to see themselves as researchers investigating a real-life case study. Students dive into hands-on science right away in the introductory LSLC activities in which they learn how to properly use lab equipment (e.g. micropipettes) and learn the importance of using personal protective equipment (gloves and goggles).

To ensure the students' safety and to enable rapid results, most LSLC hands-on activities use simulations of biological samples (such as blood and urine). For example, an HIV vaccine development activity does not use actual samples of human blood. Rather, simulated "blood" samples were designed to respond in the same ways as real samples, using chemical lab reagents (buffers and $\mathrm{pH}$ indicator solutions) instead of body fluids. The use of these types of simulations allows LSLC participants to safely learn the scientific concepts and experience the tools used in authentic life sciences laboratories (Markowitz and Holt, 2011).

LSLC activities also contain modifications and simulations to address time constraints. LSLC Field Trips are approximately 3 hours in length, which is not enough time to complete certain types of authentic lab procedures (such as PCR, ELISA, and bacterial cell transformation). Therefore, LSLC activities simulate some of these lengthy lab procedures so that the students can complete the field trip activities within a 3-hour time frame. These types of simulations have enabled the LSLC participants to learn hands-on lab skills and techniques such as bacterial cell transformations in 30 minutes compared to several days of preparation when using real bacterial samples and real DNA plasmids.

With safety and time concerns taken care of, the LSLC is able to provide an authentic learning experience for participants. LSLC programs make "real" science accessible in order to increase students' enthusiasm for science. Even with the simulations used, LSLC participants are able to experience lab skills and lab techniques used by "real" scientists. The LSLC is housed within an authentic research setting. The LSLC teaching labs were formerly research labs, which were renovated to make them more appropriate for teaching large groups of students. The proximity of the LSLC to "real" scientists is of great benefit to its programs and participants. UR researchers frequently offer their expertise - which can range from collaborating with LSLC staff on new curriculum materials (sometimes based directly on their own research), or through teaching in the field trip and inschool programs. These interactions with UR scientists have allowed participants to meet a "real scientist" and learn from real-life case studies across the life sciences. An added benefit in having the LSLC housed within an academic medical center is when researchers offer lab supplies and equipment that they no longer need. The LSLC has obtained generous donations of surplus lab supplies and equipment from research labs that are happy to see the items used by young science learners. 
Table 4. Life Sciences Learning Center Field Trip Participation 20012019. Data collected from 2001-2002 to 2018-2019 academic school years.

\begin{tabular}{cccc}
\hline Academic School Year & $\begin{array}{c}\text { Number of } \\
\text { Schools }\end{array}$ & $\begin{array}{c}\text { Number of } \\
\text { Teachers }\end{array}$ & $\begin{array}{c}\text { Number of } \\
\text { Participants }\end{array}$ \\
\hline $2001-2002$ & 24 & 32 & 1014 \\
$2002-2003$ & 34 & 46 & 1165 \\
$2003-2004$ & 42 & 59 & 1712 \\
$2004-2005$ & 44 & 59 & 2386 \\
$2005-2006$ & 35 & 49 & 2116 \\
$2006-2007$ & 34 & 49 & 1699 \\
$2007-2008$ & 34 & 46 & 1506 \\
$2008-2009$ & 33 & 43 & 1497 \\
$2009-2010$ & 36 & 50 & 1792 \\
$2010-2011$ & 35 & 57 & 1707 \\
$2011-2012$ & 43 & 58 & 1577 \\
$2012-2013$ & 26 & 30 & 835 \\
$2013-2014$ & 6 & 6 & 142 \\
$2014-2015$ & 6 & 8 & 224 \\
$2015-2016$ & 9 & 11 & 619 \\
$2016-2017$ & 9 & 11 & 840 \\
$2017-2018$ & 9 & 11 & 290 \\
$2018-2019$ & 9 & 11 & 557 \\
\hline Total & 468 & 616 & 21678 \\
\hline & & & \\
\hline
\end{tabular}

\section{EXPANSION AND SUSTAINABILITY}

National Dissemination of LSLC Curriculum. In addition to its numerous on-site and in-school programs, the LSLC began creating classroom curricula and providing teacher professional development workshops to meet the rising demands from science teachers (Figure 3, Table 6). LSLC's classroom-based curricula are developed, piloted, and field tested in a team design approach with input from topical experts including researchers, curriculum development experts, and state level science teacher organizations (Figure 2). Local teachers are also instrumental in partnering with LSLC staff in the development of classroom materials aligned with New York state education requirements.

As requests grew beyond Rochester from teachers who were interested in using LSLC lessons in their own classrooms, the LSLC began to offered teacher workshops at state and national conferences (Table 6). Each year, LSLC staff travel to lead workshops at national conferences sponsored by the National Science Teachers Association (NSTA) and the National Association of Biology Teachers (NABT). Additionally, the LSLC has provided professional development by hosting multi-day national conferences covering health science topics, for example the "LSLC Biology of Drug Abuse and Addition Conference" and the "LSLC Medicines and Me / Big Data and Health Conference" (Table 6). Teachers who attend these LSLC-led professional develop- ment programs are also encouraged to lead their own workshops, using LSLC provided materials. These teacher-led, peer-to-peer workshops enable the LSLC to further expand the reach of its lesson dissemination (Figure 3).

In order to meet the growing demands of teachers who wanted access to LSLC hands-on materials without needing to prep the materials themselves, in 2008 the director of the LSLC created Science Take-Out, a woman-owned small business that sells science kits based on LSLC- developed lessons. Science Take-Out has obtained its own sustainable funding stream through the NIH Small Business Innovation Research (SBIR) and Small Business Technology Transfer (STTR) grant mechanisms. The LSLC and Science TakeOut remain close collaborators. For example, several of the LSLC's curriculum writers also work as curriculum writers for Science Take-Out. Additionally, the robust process that Science Take-Out created to develop and evaluate their kits was later adopted by the LSLC as its curriculum development model.

The curriculum development model for LSLC classroom lessons includes an iterative multi-step process of lesson development, pre/post-assessment tests for students, and evaluation surveys completed by participating teachers (Figure 2). LSLC lesson development begins with surveying science teachers about their curriculum needs related to a specific topic or content area. Then LSLC curriculum writers create brief summaries of possible LSLC lessons. Teachers then complete online surveys to provide feedback on these possible LSLC lessons, ranking each lesson based on the potential for the lesson to engage their students and correlation

Table 5. Demographics of Schools Participating in Life Sciences Learning Center Outreach Programs. The diverse settings of schools that attended LSLC outreach programs from 2001-2019 (N=155). Schools attend LSLC Outreach programs annually or multiple times per year. Each school listed is only represented once.

\begin{tabular}{lc}
\hline $\begin{array}{l}\text { School } \\
\text { (Setting) }\end{array}$ & $\begin{array}{c}\text { Outreach Programs } \\
\text { (Field Trip, On-the-Road) }\end{array}$ \\
\hline Urban & 49 \\
Suburban & 47 \\
Rural & 59 \\
& \\
Public & 122 \\
Private & 23 \\
Other (charter) & 10 \\
& \\
Primary school (grades PreK-2) & 4 \\
Elementary school (grades 3-5) & 13 \\
Middle school (grades 6-8) & 30 \\
High school (grades 9-12) & 90 \\
Other (college, informal) & 18 \\
\hline
\end{tabular}




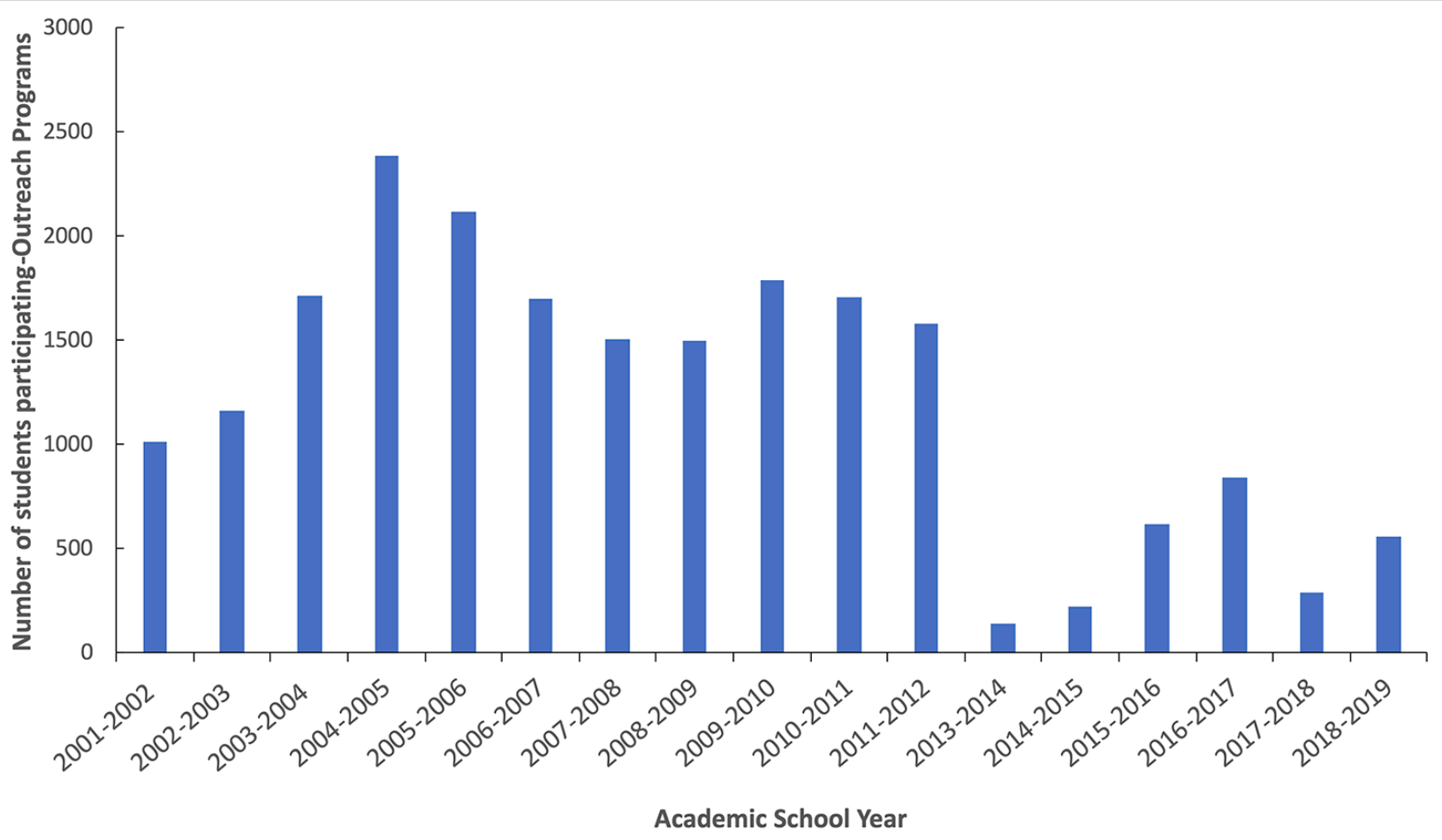

Figure 4. Participation in Life Sciences Learning Center Outreach Programs. Outreach program participants attended LSLC Field Trips and On-the-Road programs. Data collected from 2001-2002 to 2018-2019 academic school years.

of the lesson with their existing curriculums. Focus groups of science teachers then review draft versions of the LSLC lessons. The LSLC lessons then undergo several rounds of in-classroom pilot testing, which also serves to create the valid and reliable pre/post-assessments. The final step in the LSLC curriculum development model is wide-scale, national field testing and collection of pre/post-test data.

With its third SEPA project ("LSLC: Strengthening Connections between Scientists and Classroom Learning"), the LSLC began to archive its teacher resources online, further evolving its model for creating and widely disseminating classroom curricula (Figure 2, Table 6). Classroom lessons and other teacher resources such as animations, videos, and PowerPoint presentations became accessible for free download on the LSLC website via an online request. To-date over 10,000 online requests for LSLC classroom materials have been submitted. The LSLC website is also used to announce upcoming outreach programs, such as new Field Trips and community-based programs.

The priorities of the LSLC evolved further with the funding of its fourth SEPA grant ("Medicines and Me: Understanding and Using Medicines Safely") which focused on outreach programs and classroom lessons related to the safe use of over-the-counter medicines (Alcena-Stiner et al., 2020). LSLC Field Trip programs had grown over the years to include an extensive "menu" of offerings, requiring a lot of space for storing equipment and supplies and a complicated schedule for the teaching lab set-up and take-down, since a different Field Trip could be run on each day of the week. It was decided that LSLC should offer fewer Field Trip selections, but make those selections highly evaluated and closely aligned with the new national Next Generation Science Standards (NGSS). It was also decided that the LSLC Field Trip programs should complement the LSLC-developed classroom lessons.

The LSLC started its fifth SEPA project ("One Health Education: Connecting Humans, Animals, and the Environment") in 2019, marking over 20 years of NIH SEPA funding. Staying true to its evolving theme, the LSLC continues to provide hands-on informal science experiences as it adapts to the needs of formal educators and the demand for hands-on engaging STEM outreach programming.

Funding for Sustainability. Through the past $20+$ years of successful programming and funding, the LSLC has evolved into a sustainable model. The LSLC facility was launched in 2001, but pre-college science, technology, engineering, and mathematics (STEM) outreach programs were supported at UR well before the LSLC opened its doors. Early support from the Howard Hughes Medical Institute (1994-1999) and the Foundation for Microbiology (1995-1997) provided seed funding to UR for middle and high school level STEM programming (Figure 1 and Table 1). UR-SMD's first SEPA grant was awarded by the NIH National Center for Research and Resources in 1998 (Table 2). This 2-year, Phase I SEPA grant funded summer and school vacation science programs that were held in the UR medical school laboratories and classrooms. Additional funding from the Rochester Area 


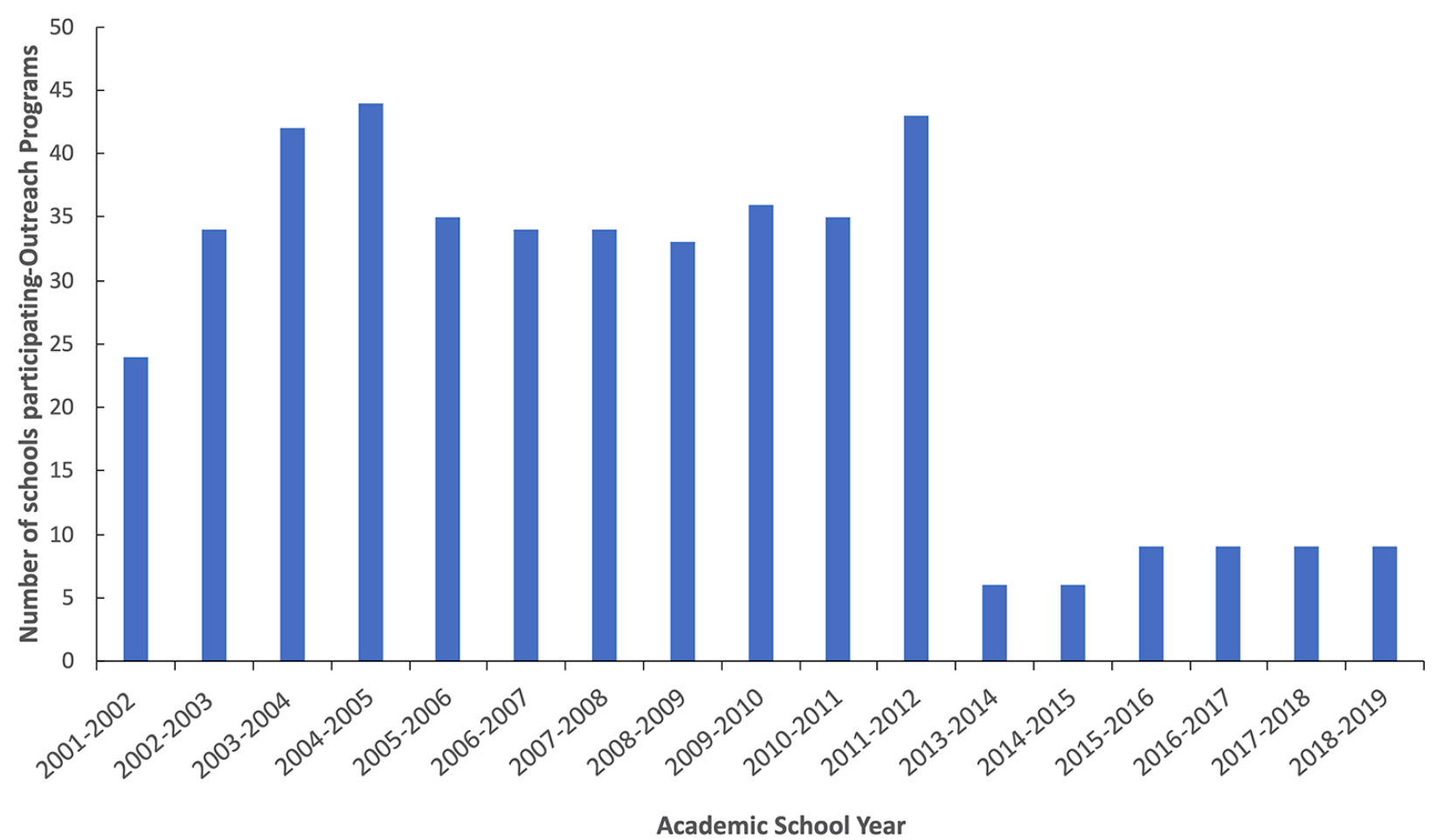

Figure 5. School Participation in Life Sciences Learning Center Outreach Programs. Outreach program participants attended LSLC Field Trips and On-the-Road programs. Data collected from 2001-2002 to 2018-2019 academic school years.

Community Foundation, Willmott Foundation, and Eastman Kodak (Table 1) supported science teacher professional development programs to enhance in-school science activities during class time.

The UR-SMD outreach programs were awarded two additional NIH grants in 2000, a R25 grant from the National Institute of Environmental Health Sciences (NIEHS), and a pilot project award from the UR Environmental Health Sciences Center (EHSC), funded through their NIEHS P30 Center grant (Table 2). Success continued with a Phase II SEPA grant, awarded in 2001, which provided the support to establish an actual outreach center facility located within the UR Department of Environmental Medicine. The center was named the Life Sciences Learning Center (LSLC) to be inclusive of the wide variety of biomedical science disciplines covered by UR's pre-college outreach programs.

In 2002, the LSLC received additional pilot project sup- port from the NIEHS P30 award as well as a grant from the Toyota USA Foundation (Table 1). These funds were further supplemented with additional grants from the Braitmayer Foundation and the Howard Hughes Medical Institute (HHMI) in 2003, the Arthur Vining Davis Foundation in 2007, and Time Warner Cable in 2010 (Table 1).

The LSLC secured its third NIH SEPA award in 2006 as the demand for science outreach programming began to extend beyond the Greater Rochester area (Table 2). This SEPA grant funded on-site programming at the LSLC facility as well as LSLC classroom lessons which were disseminated widely throughout the US. Additional NIH support from the National Institute on Drug Abuse (NIDA) in 2009 and the Neuroscience Blueprint (2011) and a fourth SEPA grant (2014) led to additional on-site outreach programming and also furthered the LSLC's ability to widely disseminate its curriculum materials throughout the US (Table 2).

Table 6. National Dissemination of Life Sciences Learning Center Classroom Curriculum. Acronyms: National Institutes of Health (NIH), Science Education (SciEd), Conference for the Advancement of Science Teaching (CAST).

\begin{tabular}{lll}
\hline Conference & Participation Years & Format \\
\hline National Science Teachers Association & $2006,2011-2015,2017-2019$ & Workshop (all years)/STO Exhibitor booth (2011-2019) \\
National Association of Biology Teachers & $2006,2013,2014,2019$ & Workshops (all years)/STO Exhibitor booth (2013-2019) \\
NIH SciEd Conference & $2012-2019$ & Posters/Breakout sessions \\
Project Lead the Way (PLTW) Summit & $2017-2019$ & Workshops/STO Exhibitor booth \\
CAST (TX Science Teachers) & $2011-2013$ & Workshops/STO Exhibitor booth \\
LSLC Biology of Drug Abuse and Addiction Conference & 2012 & 3-day conference \\
LSLC Medicines and Me/Big Data and Health Conference & 2017 & 3-day conference \\
\hline
\end{tabular}



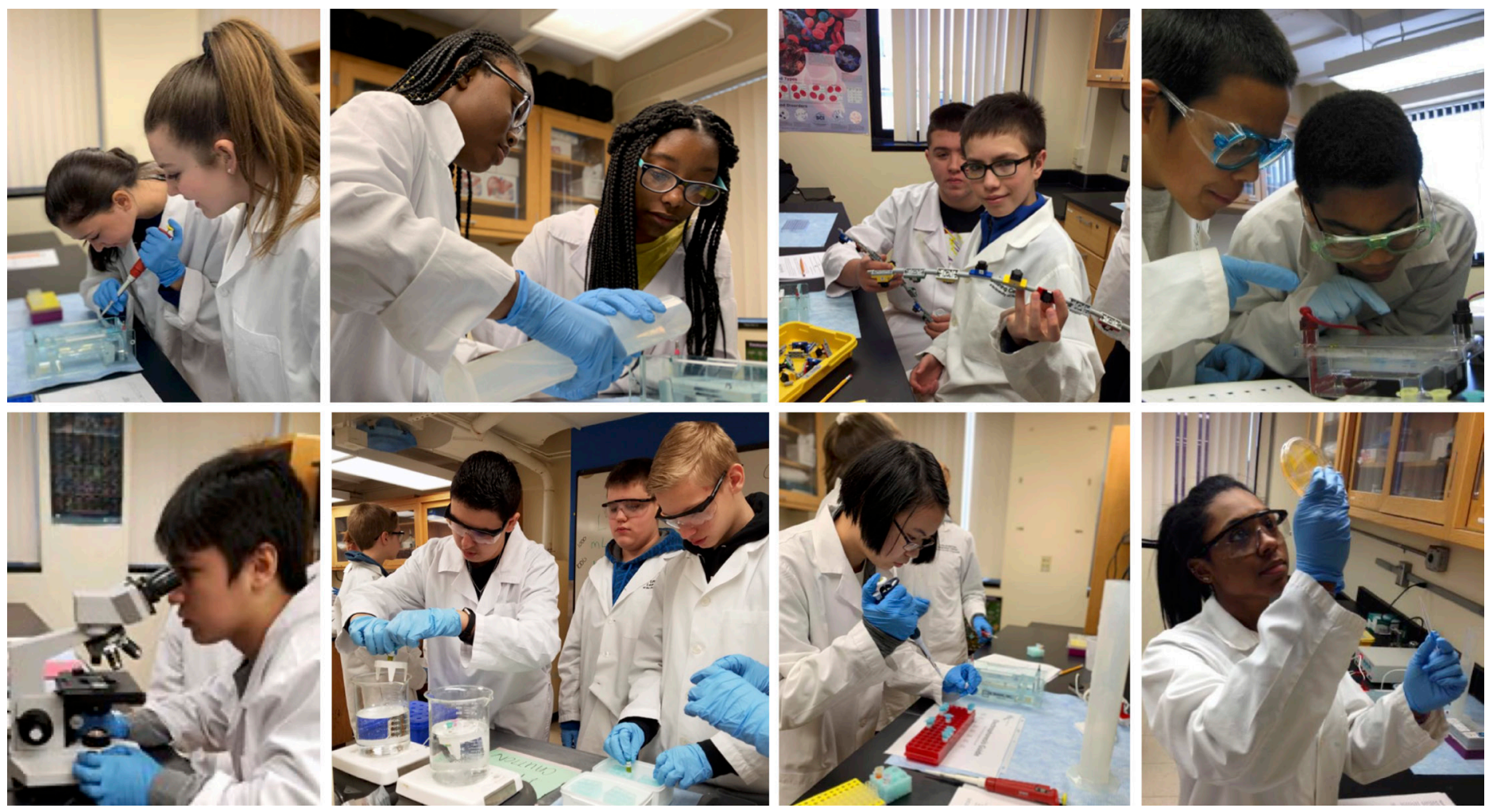

Figure 6. Experiential Programs at the Life Sciences Learning Center. Images depict LSLC participants engaged in hands-on activities as part of the LSLC Outreach Field Trip programs. Participants use modern lab equipment (Electrophoresis gel boxes, micropipettes, microscopes, petri dishes etc.).

Funding Challenges and Perseverance. The LSLC is solely supported by grants, mostly from the NIH, which have been used for setting up the initial facility (for purchasing equipment and supplies) and for faculty and staff salaries. The NIH grants also provide indirect costs ("overhead") to the University, which are used to provide departmental support for the grant awards and operational costs such as basic building maintenance. Although, the University does not provide financial support to the LSLC, the UR-SMD provided funding in 2001 to combine and renovate several research laboratories, which became the larger of two LSLC teaching labs. As LSLC programs grew, UR-SMD provided funding to renovate additional research labs, and a second LSLC teaching lab was added in 2003. The LSLC operational budget is supplemented by outreach program fees that are collected for field trips and On-the-Road programs. Once an LSLC field trip or On-the-Road program has been fully developed, it switches from a free program (funded by a SEPA grant) to a fee-based program. Field trip fees range between \$15-\$20 per student, depending on the particular field trip program. The fee for LSLC One-the-Road programs range between \$13-18 per participant, depending on the program

The LSLC structure changed over the years due to reduced funding, resulting in fewer types of programs offered (Figure 4, Figure 5). For example, in previous years when the LSLC was supported by several different grants at one time (each on a different topic), it would offer as many as a dozen different Field Trips for schools to select from. In more recent years, the LSLC has been funded by only one SEPA grant, therefore the focus for LSLC's curriculum writers was narrowed. LSLC outreach selections have been pared down to 2-4 field trips now being offered during a particular school year. The LSLC was able to lower its operating cost by offering fewer sections of field trips, since this requires less equipment and supplies to be kept on hand. The LSLC's programs now focus exclusively on grant-funded projects and the outreach programs (i.e. the LSLC field trips and Onthe-Road programs) correlate with the classroom lessons and align to NGSS standards. The LSLC will also continue to seek institutional support to sustain opportunities for communities burdened by the cost of LSLC programming.

Partnership Challenges and Perseverance. The LSLC has had many challenges over the years related to partnerships with the State, school districts, and the University.

State. The New York State Biology Mentor Network was a statewide organization of master teachers which served to foster ongoing professional growth for biology educators. The Mentor Network partnered with the LSLC on several projects to develop and disseminate curriculum materials and student-centered teaching strategies (Figure 3). The Mentor Network provided a broad teacher base for partnerships and access to master teachers to evaluate, pilot/field- 
test, and disseminate LSLC's classroom curriculum materials to other science teachers throughout the state. However, when the state discontinued funding to the Mentor Network, the LSLC lost a valuable partner. Some Mentor Network teachers have continued to partner with the LSLC individually, without the State support (they are supported instead by the LSLC's SEPA grants). These former Mentor Network teachers remain very valuable partners to the LSLC.

School Districts. Local school districts have experienced shifts in administration, educational policies and funding making it challenging to sustain long-term programming partnerships. Many local school districts have also experienced budget cuts, and schools that participated in LSLC Field Trips in previous years no longer have funding for Field Trips. Some schools are only able to attend LSLC Tield Trips in development, which are funded by grants. Additionally, the restructuring and abrupt changes to teaching staff can be cumbersome to outreach program planning. Moreover, challenges have been observed prior to and immediately following the implementation of Next Generation Science Standard (NGSS). During outreach programs preNGSS, schools expected the LSLC to give students' experience in "real" hands-on science, regardless of the Field Trip topic. However, post-NGSS, schools exclusively wanted LSLC programs which directly aligned to NGSS. The LSLC programming and classroom curriculum adapted to have content with alignment to NGSS to meet teacher curriculum and experiential learning needs.

University. In past years, UR graduate students who are interested in informal science education could volunteer to teach or assist with LSLC programs. Graduate student volunteers would lend a hand as their schedules permitted - weekly at times and once a month or less frequently at other times. This flexibility was very appealing to graduate students. However, in recent years the University's guidelines and policies changed, so graduate students could no longer volunteer at the LSLC - they needed to be involved in formal (unpaid) semester-long internships. Such formality created a hindrance, since many graduate students preferred a less formalized volunteer opportunity to the more formalized internship position. The result is that fewer graduate students are applying to be LSLC interns. Moreover, due to the 2019 coronavirus (COVID-19) pandemic, the University was closed to all visitors. This resulted in the cancelations of all in-person LSLC activities and restructuring of LSLC programs to remote options only. Additionally, the recent lost revenue related to COVID-19 will be an obstacle in requesting sustainable funding from the University budget. Lastly, the cost of programming has been a challenge over the years. The LSLC can only offer fee waivers for outreach programs when there is grant support during lesson development.
When lessons have been developed, the cost for outreach programs is deferred to participants, which can be a burden for some communities. This has been a challenge from not having direct University support to sustain opportunities for local schools who do not have the budget to cover transportation, participation fees, or substitute teachers (to cover classes when teachers leave the school to attend the LSLC Field Trip programs).

LSLC Sustainability into the Future. The future directions for LSLC sustainability include expanding the breadth of programming to connect STEM knowledge and health literacy, by creating LSLC outreach content for health professional use. LSLC is also exploring ways to disseminate its Field Trips and On-the-Road lessons broadly to other STEM outreach organizations, alongside the LSLC classroom curriculum materials which are disseminated nationwide. The LSLC is also developing new methods to offer hands-on activities alongside the growing demand for online curricula. The LSLC is currently exploring new approaches for evolving the outreach programs in the future to meet the growing needs of the community.

The LSLC's NIH SEPA projects have also been gradually adapting. The initial LSLC focus was deeply rooted in hands-on approaches for increasing students' STEM knowledge and enthusiasm for science, using case-based learning with authentic science tools (microscopes, pipettes, etc.). Although the LSLC projects have always contained areas for expansion into health literacy (i.e. brain health, medicine safety, environmental health), health literacy was not part of the LSLC focus in its initial mission or strategic plan. The LSLC's most recent past SEPA project ("Medicines and Me: Understanding and Using Medicines Safely") directly connected STEM concepts to health literacy. The LSLC's current NIH SEPA project (“One Health Education") will guide learners to think critically about the integration of science and health into their everyday lives. LSLC "One Health" lessons and Field Trip programs that are in development will focus on real-world science issues that connect the health of humans, animals and the environment in order to promote the health of all. Moreover, LSLC's One Health programs will provide appropriate context for participants to connect the current effects of animal-borne disease transmissions that have the potential to cause pandemics such as COVID-19. These lessons and Field Trips are geared towards middle and high school students (grades 6-12). Nonetheless, the LSLC has been approached over the years to develop lessons for elementary teachers. Therefore, supplemental funding may expand "One Health" lesson content to lower grade levels.

The LSLC is establishing new partnerships with researchers whose work is focused on adolescent health literacy. These partnerships will promote the health and wellness of adolescents through LSLC outreach programs and class- 
room lessons. These new partnerships also have the potential to further evolve the LSLC beyond its initial missions and adapt towards the promotion of health and wellness for all learners, from elementary students through older adults. This will be done using the LSLC's keen ability to create hands-on science inquiry lessons that make advanced science concepts understandable to diverse learners. To this end, the LSLC's professional development participant focus may expand beyond teachers in traditional classroom settings. New professional development workshops may reach into community settings of health professional educators, such as nurses in schools, hospitals, and clinics. The health promotion and wellness of adolescent populations through the integrations of life sciences and health will be a theme for future LSLC grant funding to support the development of new classroom curricula and community engagement, further evolving the LSLC outreach programs into the future.

With each new LSLC project in development, the center will aim to align the content of classroom curriculum with LSLC outreach programming. This evolution in approaches will enable the dissemination of LSLC Field Trip and Onthe-Road lessons broadly alongside the LSLC classroom curriculum materials (Figure 2). The application of the model established for dissemination of LSLC classroom curricula to the dissemination of LSLC outreach programs will allow other outreach organizations to benefit from the LSLC's model of sustainability.

\section{AUTHOR INFORMATION Corresponding Author}

Danielle C. Alcéna-Stiner. University of Rochester. School of Nursing. 601 Elmwood Avenue, Box SON. Rochester, NY 14642. Danielle_Alcena@urmc.rochester.edu

\section{Author Contributions}

The manuscript was written through contributions of all authors. All authors have given approval to the final version of the manuscript.

\section{ACKNOWLEDGMENTS}

The authors acknowledge University of Rochester faculty member and retired New York State teacher, Susan Holt and countless teachers for their active roles in the development of LSLC classroom curricula over the years. Additionally, the collaborative support from the University of Rochester community enables the LSLC access to topical experts in program development. Most notably, the LSLC would not exist without participants who partake in hands-on, casebased learning developed to not only boost their science literacy but also increase their enthusiasm toward science learning.

\section{FUNDING SOURCES}

The projects and activities described in this article were supported by National Institutes of Health Science Education Partnership Award grants (R25RR012411, R25RR023285, R25OD10494, R25GM132758), National Institute on Drug Abuse grants (R25DA032998, R25DA021697), National Institute of Environmental Health Sciences grants (P30ES001247, R25ES010717), a National Human Genome Research Institute grant (25HG002756), and from private foundations acknowledged in the article. Authors have no conflicts of interest to disclose.

\section{ABBREVIATIONS}

CAST: Conference for the Advancement of Science Teaching; EHSC: Environmental Health Sciences Center; ELISA: Enzyme-Linked Immunosorbent Assays; HHMI: Howard Hughes Medical Institute; LSLC: Life Sciences Learning Center; NGSS: Next Generation Science Standards; NIDA: National Institute on Drug Abuse; NIEHS: National Institute of Environmental Health Sciences; NIH: National Institutes of Health; PCR: Polymerase Chain Reaction; RCSD: Rochester City School District; SciEd: Science Education; SEDAPA: Science Education Drug Abuse Partnership Award; SEPA: Science Education Partnership Award; SSA: Summer Science Academy; STEM: Science, Technology, Engineering, and Mathematics; STO: Science Take-Out; UR-SMD: University of Rochester School of Medicine and Dentistry; US: United States

\section{REFERENCES}

Alcéna-Stiner, D., Holt, S., Montes, G., and Markowitz, D. (2020). Medicines and Me: Hands-On health literacy lessons for adolescents. Journal of Adolescent Health, 66(2), S69-S70. doi:10.1016/j.jadohealth.2019.11.139

Luehmann, A. L. (2009). Students' perspectives of a science enrichment programme: Out-of-school inquiry as access. International Journal of Science Education, 31(13), 18311855. doi:10.1080/09500690802354195

Markowitz, D., and Holt, S. (2011). SIMULATING SCIENCE: Manipulative models and small-scale simulations that promote learning of complex biological concepts. The Science Teacher, 78(5), 44-48. Retrieved from www.jstor.org/ stable/24148128

Markowitz, D. G. (2004). Evaluation of the long-term impact of a university high school summer science program on students' interest and perceived abilities in science. Journal of Science Education and Technology, 13(3), 395-407. Retrieved from www.jstor.org/stable/40186659 